\title{
CHEMICAL COMPOSITION AND ANTIBACTERIAL ACTIVITY OF THE ESSENTIAL OIL OF THE Toona sureni (Blume) Merr
}

\author{
M. Taufik Ekaprasada ${ }^{1}$, Hazli Nurdin ${ }^{2}$, Sanusi Ibrahim ${ }^{2}$, Dachriyanus ${ }^{3}$ \\ ${ }^{1}$ Department of Industry, Indonesia \\ ${ }^{2}$ Department of Chemistry Andalas University, Padang 25163 Indonesia \\ ${ }^{3}$ Faculty of Pharmacy Andalas University, Padang 25163 Indonesia \\ email : em.taufik@yahoo.com
}

\begin{abstract}
The essential oil composition of the Toona sureni (Blume) Merr leaf was analyzed by GC-MS. More than 68 peaks, representing $99.99 \%$ of total oil, forty three components were identified, this represents $80.65 \%$ of the total oil component. The major components were $\alpha$-terpinene $(9.58 \%), \alpha$ copaene $(8.39 \%)$, bicyclogermacrene $(7.61 \%), \delta$-cadinene $(6.65 \%), \quad \beta$-elemene $(4.88 \%)$, germacrene-D $(4.65 \%), \delta$-selinene $(3.58 \%)$, caralene $(3.10 \%), \beta$-caryophyllene $(2.88 \%), \alpha$ cubebene $(2.82 \%), \delta$-gurjunene $(2.20 \%)$, and (-)-isoledene $(2.05 \%)$. The antibacterial activity of the essential oil of Toona sureni (Blume) Merr leaf was evaluated using disk diffusion method. The oil was effective on the inactivation of Escherichia coli, Staphylococcus aureus and Bacillus subtilis.
\end{abstract}

Keywords: Toona sureni (Blume) Merr, antibacterial activity, GC-MS, essential oil

\section{INTRODUCTION}

World Health Organization (WHO) noted that majority of the world's population depends on traditional medicine for primary healthcare. Medicinal and aromatic plants which are widely used as medicine and constitute a major source of natural organic compounds ${ }^{[1]}$.

The essential oils are complex mixers comprising many single compounds. Chemically they are derived from terpenes and their oxygenated compounds. The essential oils have been shown to possess antibacterial. They demonstrated an interesting selectivity as its have a modes antimicrobial activity against some the tested gram-positive and gramnegative strains ${ }^{[2-10]}$.

Toona sureni (Blume) Merr is one of among five or six species of trees in the mahogany family Meliaceae ${ }^{[11]}$. Indonesia it is found in Sumatra, Java and Sulawesi. Various parts of the tree, especially the bark and root, are used for medicinal purposes, e.g. to treat diarrhoea. Leaf extracts have antibiotic effect. The bark and fruits can be used for production of essential oils ${ }^{[12]}$.

The literature search revealed that a number different compounds have previously been isolated from the leaves of the plant, including tetranortriterpenoid (surenin, surenone and surenolactone $)^{[13,14]}$, and carotenoids ${ }^{[15-16]}$. Another species of Toona genus, Toona ciliate contains the essential oil from the leaves $(0.05 \%, \mathrm{~V} / \mathrm{W})$ and the stems $(0.05 \%, \mathrm{~V} / \mathrm{W})$. The oil contains $\beta$-caryophyllene, germacrene$\mathrm{D}$ and bicyclogermacrene as the major compounds ${ }^{[17]}$.

Toona sinensis contains the essential oil from the leaves $(0.02 \%, \mathrm{~V} / \mathrm{W})$. The oil contains germacrene- $\mathrm{D}$, germacrene- $\mathrm{B}, \alpha$-terpinene, $\alpha$ humulene, $\quad \beta$-caryophyllene, $\alpha$-elemene, bicyclogermacrene and $\alpha$-copaene as the major compounds ${ }^{[18]}$.

Herein we report the chemical composition of and antibacterial activity of the essential oil from the leaves of the Toona sureni (Blume) Merr. 


\section{MATERIALS AND METHODS}

\section{Plant Material}

Plant materials were collected in Padang, West Sumatera, Indonesia in Juli 2007, and identified in the Herbarium of the Andalas University (ANDA), Padang, with specimen M.Taufik Ekaprasada, 0107 (ANDA.Fr).

\section{Isolation of Volatile Oil}

The fresh leaves of Toona sureni (Blume) Merr $(6500 \mathrm{~g})$ were sliced and subjected to steam distillation $(4 \mathrm{~h})$ to yield $(0.04 \%)$ oil. The work was repeated to produce the oil that enough for analysis. The oil was dried over anhydrous sodium sulfate and stored at low temperature prior to analysis. The oil obtained was greenish yellow with a strong odor. The physicochemical characteristics of the oil were determined according to AFNOR ${ }^{[19]}$ standards at $20^{\circ} \mathrm{C}: \mathrm{d}(20 ; 20)=0.9197, \mathrm{n}(\mathrm{D} ; 30)=1.5085$.

\section{Identification Components}

Identification of volatile compounds was performed using gas chromatography-mass spectrometry (GC-MS). The component relative concentrations in each essential oil were calculated based on GC peak areas. Each oil was analyzed by GC-MS using a Agilent Technologies 6890 Gas Chromatograph with Auto Sampler and 5973 Mass Selective Detector and Chemstation data system with a Innowax Capilarry Coloumn $(30 \mathrm{~m} \times 0.25 \mathrm{~mm}$ I.D $\times 0.25 \mu \mathrm{m}$ film thickness). $\mathrm{GC}$ oven initial temperature was $65^{\circ} \mathrm{C}$ hold for a minute, rising at $3^{\circ} \mathrm{C} / \mathrm{min}$ to $150^{\circ} \mathrm{C}$ for 2 minutes, rising at $15^{\circ} \mathrm{C} / \mathrm{min}$ to $240^{\circ} \mathrm{C}$ for 20 minutes. Injection port temperature at $250^{\circ} \mathrm{C}$; ion source temperature at $230^{\circ} \mathrm{C}$, interface temperature at $280^{\circ} \mathrm{C}$, quadrupole temperature at $140^{\circ} \mathrm{C}$, carrier gas was helium, flow column: 0.6 $\mu \mathrm{L} / \mathrm{min}$, injected volume: $1 \mu \mathrm{L}$, split: $250: 1$, method file was AKRWAX.

The mass spectra were performed at $70 \mathrm{eV}$ with ionization mode: electron impact. Identification of the constituents was based on comparison of the retention times with those of authentic samples on computer matching against commercial libraries (Wiley $275 \mathrm{~L}$ ).

\section{Test Organism}

Microorganisms were obtained from the Department of Biology Faculty of Mathematic and Natural Science, University of Andalas, Padang, Indonesia. A strain of gram-negative bacteria (Escherichia coli) and two strains of gram-positive bacteria (Bacillus subtilis and Staphylococcus aureus) were used. The cultures of bacteria were maintained in their appropriate agar slants at $4^{\circ} \mathrm{C}$ throughout the study and used as stock cultures.

\section{Antibacterial Assay}

The disk diffusion susceptibility method was used in order to examine the sensitivity of the bacteria of interest toward the essential oil of the Toona sureni (Blume) Merr. Antimicrobial assay was measured using the methods of Rojas, J. et. $a l^{[20]}$ but with slight modifications. One loopful of the given test strain was inoculated into $2.5 \mathrm{~mL}$ of N-broth (Nutrient Broth) and incubated for $24 \mathrm{~h}$ in an incubator at $37^{\circ} \mathrm{C}$ in order to activate the bacterial strain.

The bacterial inoculum was diluted in the sterile saline solution $(0.9 \% \mathrm{NaCl})$ to obtain turbidity visually comparable to a McFarland No. 0.5 Standard $\left(10^{6-8} \mathrm{CFU} / \mathrm{mL}\right)$. Mueller Hinton Agar (MHA), sterilized in a flash and cooled to $40-50^{\circ} \mathrm{C}$, was poured $(15 \mathrm{~mL})$ into sterilized Petri dishes (9 $\mathrm{mm}$ diameter) and allowed to harden under room temperature. This is followed homogenous distribution of $0.1 \mathrm{~mL}$ bacteria culture $\left(10^{6-8} \mathrm{cfu} / \mathrm{mL}\right)$ onto medium in Petri dishes. The essential oils were dissolved in dimethylsulfoxide (DMSO).

The sterile paper disk ( $5 \mathrm{~mm}$ diameter) was impregnated with $20 \mu \mathrm{L}$ of the different dilutions, $10,5,3,1,0.75,0.625,0.5,0.375$, 0.25 , and $0.125(\% \mathrm{v} / \mathrm{v})$, of the previously prepared solution. The reading of the plates, incubated at $37^{\circ} \mathrm{C}$, showed after $48 \mathrm{~h}$ inhibitory zones around the paper disks. When the inhibitory zone diameter is lower or equal to 5 $\mathrm{mm}$, the sample tested was considered as not active. The minimum inhibitory concentration (MIC) was determined as the lowest concentration of the test compound that demonstrated no visible growth. Chloramphenicol; 3\% (b/v) as the standard antibiotic used in order to provide a control for 
the sensitivity of the test organisms in the experiments. Two replicates were performed for each analysis.

\section{RESULTS AND DISCUSSION}

\section{Essential Oils}

After four hours of steam distillation, the essential oil yield was $0.04 \%(\mathrm{v} / \mathrm{b})$. The chromatogram of the essential oil is given in Figure 1 and the composition of the essential oil is given in Table 1. Component concentrations were calculated from GC peak areas. Out 68 peaks, representing 99.99\% of total oil, forty three components were identified, this represents $80.65 \%$ of the total oil component.

Inspection of Table 1 clearly shows that the oil consists largely of sesquiterpene hydrocarbons which constitute about $66.50 \%$ of the total oil with $\alpha$-copaene $(8.39 \%)$, bicyclogermacrene $(7.61 \%), \quad \delta$-cadinene $(6.65 \%), \quad \beta$-elemene $(4.88 \%)$, germacrene-D $(4.65 \%), \delta$-selinene $(3.58 \%), \quad(+)-\beta$-gurjunene $\quad(3.10 \%), \quad \beta$ caryophyllene $(2.88 \%), \alpha$-cubebene $(2.82 \%)$, $\delta$-gurjunene $(2.20 \%)$, and $(-)$-isoledene $(2.05 \%)$ as the major sesquiterpene. Furthermore, $4.57 \%$ was found to be present as sesquiterpenoid i.e, sphatulenol, torreyol, isosphatulenol, t-cadinol, t-muurolol, and $\mathrm{d}$ nerolidol.

There were only one monoterpene which accounted for $9.58 \%$ of the oil total i.e, $\alpha$ terpinene. No diterpene was found so far from the essential oil composition of this plant. Some major components of the oil $(\beta$ caryophyllene bi-cyclogermacrene, germacrene-D) also were found on the leaves of Toona ciliata and Toona sinensis as major components ${ }^{[17,18]}$.

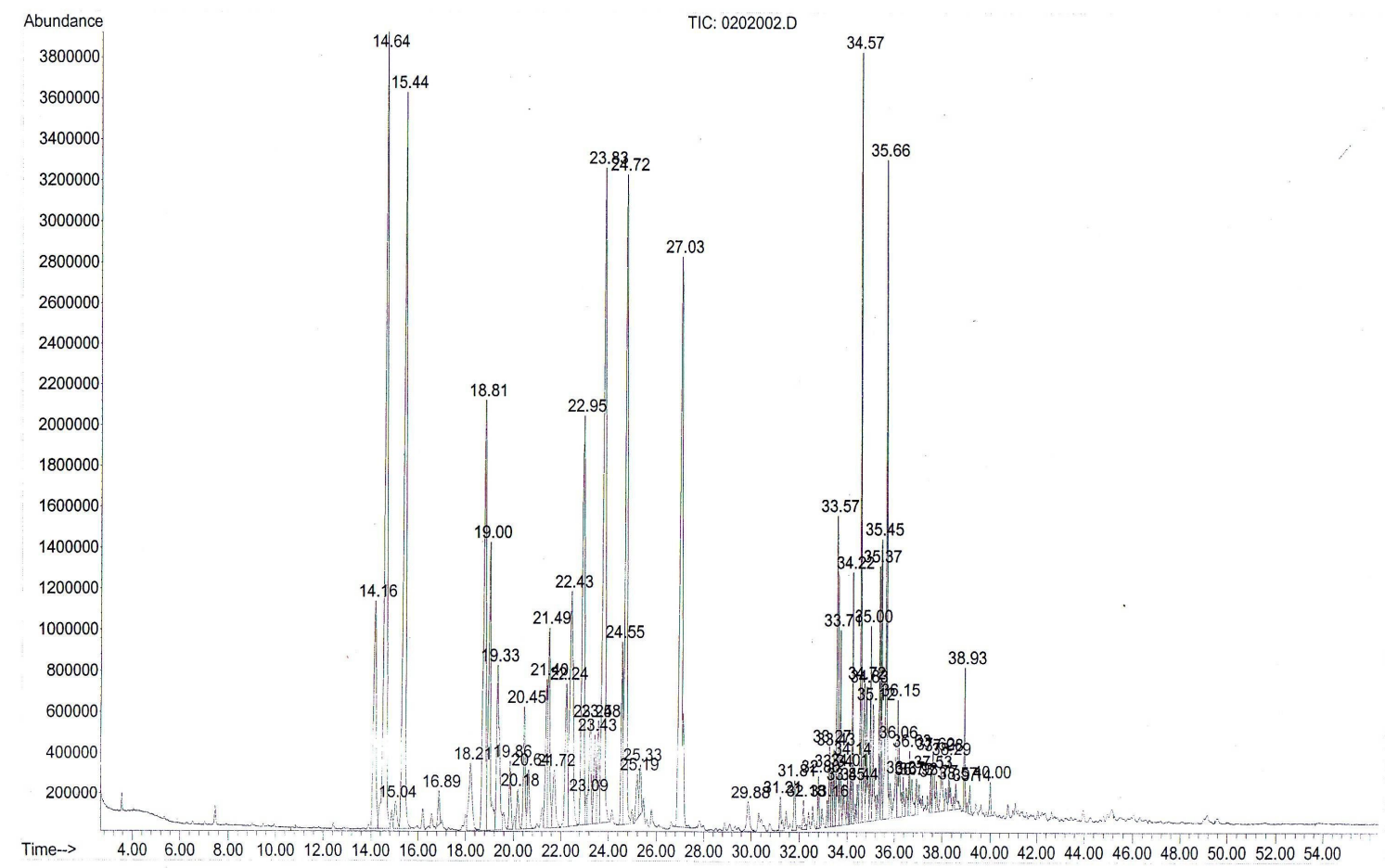

Figure 1. Chromatogram of the essential oil of the leaves of Toona sureni 
Table 1. Identified Chemical Constituents in the Essential Oil of the Leaves of Toona sureni

\begin{tabular}{|c|c|c|c|}
\hline No & Compound & $\begin{array}{l}\text { Retention } \\
\text { time (Min) }\end{array}$ & $\begin{array}{c}\text { Concentration } \\
(\%)\end{array}$ \\
\hline A & Monoterpene hydrocarbon & - & 9.58 \\
\hline 1 & $\alpha$-terpinene & 14.64 & 9.58 \\
\hline B & Sesquiterpene hydrocarbons & - & 66.50 \\
\hline 1 & $\alpha$-cubebene & 14.16 & 2.82 \\
\hline 2 & $\alpha$-copaene & 15.45 & 8.39 \\
\hline 3 & $\beta$-cubenene & 16.90 & 0.26 \\
\hline 4 & $\beta$-elemene & 18.81 & 4.88 \\
\hline 5 & $\beta$-caryophillene & 19.01 & 2.88 \\
\hline 6 & (-)-isoledene & 19.34 & 2.05 \\
\hline 7 & $(+)-\delta$-selinene & 19.87 & 0.55 \\
\hline 8 & $\gamma$-elemene & 20.46 & 1.01 \\
\hline 9 & allo-aromadendrene & 20.64 & 0.56 \\
\hline 10 & valencene & 21.40 & 1.27 \\
\hline 11 & $\alpha$-humulene & 21.49 & 1.78 \\
\hline 12 & $(+)-\beta$-guaiene & 21.72 & 0.76 \\
\hline 13 & $\alpha$-amorphene & 22.24 & 1.62 \\
\hline 14 & $\delta$-selinene & 22.44 & 3.58 \\
\hline 15 & germacrene-D & 22.95 & 4.65 \\
\hline 16 & $(+)$-aromadendrene & 23.24 & 1.08 \\
\hline 17 & $\alpha$-selinene & 23.44 & 0.88 \\
\hline 18 & $\alpha$-muurolene & 23.58 & 0.86 \\
\hline 19 & bicyclogermacrene & 23.83 & 7.61 \\
\hline 20 & $\mathrm{E}, \mathrm{E}-\alpha$-farnesene & 24.56 & 1.18 \\
\hline 21 & $\delta$-cadinene & 24.72 & 6.65 \\
\hline 22 & ar-curcumene & 25.19 & 0.45 \\
\hline 23 & epizonaren & 25.33 & 0.43 \\
\hline 24 & $\alpha$-calacorene & 29.88 & 0.38 \\
\hline 25 & calarene & 31.81 & 0.35 \\
\hline 26 & $\gamma$-gurjunene & 32.18 & 0.20 \\
\hline 27 & $\alpha$-guaiene & 32.80 & 0.30 \\
\hline 28 & $\delta$-gurjunene & 33.57 & 2.20 \\
\hline 29 & $\beta$-selinene & 33.71 & 0.85 \\
\hline 30 & $\alpha$-elemene & 33.84 & 0.28 \\
\hline 31 & $\beta$-maaliene & 34.43 & 0.22 \\
\hline 32 & $(+)-\beta$-gurjunene & 34.58 & 3.10 \\
\hline 33 & $\alpha$-gurjunene & 34.72 & 0.91 \\
\hline 34 & $\delta$-cadinene & 34.83 & 0.79 \\
\hline 35 & selin-4,7(11)-diene & 36.07 & 0.56 \\
\hline 36 & patchoulane & 37.76 & 0.16 \\
\hline $\mathrm{C}$ & sesquiterpenoid & - & 4.57 \\
\hline 1 & sphatulenol & 34.22 & 0.99 \\
\hline 2 & torreyol & 35.12 & 0.70 \\
\hline 3 & isosphatulenol & 35.38 & 0.92 \\
\hline 4 & t-cadinol & 35.45 & 1.11 \\
\hline 5 & t-muurolol & 34.99 & 0.73 \\
\hline 6 & d-nerolidol & 33.15 & 0.12 \\
\hline
\end{tabular}


Table 2. Antibacterial Activities of of Toona sureni (BI) Merr Essential Oil from the Leaves ${ }^{\mathrm{a}}$

\begin{tabular}{|c|c|c|c|c|c|c|c|c|}
\hline \multirow{2}{*}{$\begin{array}{c}\text { Bacterial } \\
\text { species }\end{array}$} & \multicolumn{6}{|c|}{ Concentrations of the oil $(\% \mathrm{v} / \mathrm{v})$} & \multirow{2}{*}{$\begin{array}{l}\text { Chloramphenicol } \\
(3 \%, b / v)\end{array}$} & \multirow{2}{*}{$\begin{array}{c}\mathrm{MIC} \\
(\% \mathrm{v} / \mathrm{v})\end{array}$} \\
\hline & 10 & 5 & 3 & 1 & 0.75 & 0.675 & & \\
\hline B. subtilis & 14 & 12 & 11 & 8 & 6 & $\mathrm{~b}$ & 31 & 0.75 \\
\hline S. aureus & 15 & 9 & 8 & 6 & 6 & $b$ & 31 & 0.75 \\
\hline E. coli & 8 & 8 & 7 & $\mathrm{~b}$ & & & 29 & 3 \\
\hline
\end{tabular}

\section{Antibacterial Activity of the Essential Oil}

Table 2 shows the antibacterial activity the oil against Gram-positive and Gram-negative bacteria. It was showed an antibacterial activity against all bacterial strains used in this study. Diameter values of the inhibitory zones of the oil are lower for Escherichia coli than Bacillus subtilis and Staphylococcus aureus. It showed that Escherichia coli is the most resistant. It was observed that Bacillus subtilus was the most sensitive to the oil. As seen in Table 2, all three bacteria show an antibacterial activity to the oil which cantains $\alpha$-terpinene (9.58\%), and $\beta$-caryophillene (2.88\%), and this is in agreement with literature reference ${ }^{[3]}$.

\section{CONCLUSION}

In conclusion, our GC and GC-MS study of Toona Sureni (Blume) Merr essential oil led to the identification of out 68 peaks, representing $99.99 \%$ of total oil, forty three components were identified, this represents $80.65 \%$ of the total oil component. The major components were monoterpene i.e $\alpha$-terpinene $(9.58 \%)$ and $\alpha$-copaene $\quad(8.39 \%), \quad$ bicyclogermacrene $(7.61 \%), \quad \delta$-cadinene $(6.65 \%), \quad \beta$-elemene $(4.88 \%)$, germacrene-D $(4.65 \%), \delta$-selinene $(3.58 \%), \quad(+)-\beta$-gurjunene $\quad(3.10 \%), \quad \beta$ caryophyllene $(2.88 \%), \alpha$-cubebene $(2.82 \%)$, $\delta$-gurjunene $(2.20 \%)$, and (-)-isoledene $(2.05 \%)$ as the major sesquiterpene. Furthermore, $4.57 \%$ was found to be present as sesquiterpenoid.

The results presented here for the antibacterial activity study demonstrate the activity of Toona Sureni (Blume) Merr essential oil and support the use of parts of this plant in used for medicinal purposes.

\section{ACKNOWLEDGEMENT}

We would like to express our deep thanks to Department of Industry for providing financial support through Industry Training and Education Centre of Republic of Indonesia. We also thank to Department of Chemistry of Faculty of Mathematic and Natural Science and Faculty of Pharmacy of Andalas University for providing the facility of our research. We also thank to Drs. Rusdi Tamin for the collection and identification of the plant material.

\section{REFERENCES}

1. S. Prabuseenivasan, M. Jayakumar, S. Ignacimuthu, In vitro antibacterial activity of some plant essential oils, $B M C$ Complementary and Alternative Medicine, 6(39): 1-8, (2006).

2. P. Lo Cantore, N. S. Iacobellis, A. De Marco, F. Capasso, F. Senatore, Antibacterial Activity of Coriandrum sativum L. and Foeniculum vulgare Miller Var. vulgare (Miller) Essential Oils, J. Agric. Food Chem., 52: 7862-7866, (2004).

3. C. Koutsoudaki, M. Krsek, A. Rodger, Chemical Composition and Antibacterial Activity of the Essential Oil and the Gum of Pistacia lentiscus Var. chia., J. Agric. Food Chem., 53, A-E, (2005).

4. N. Bendimerad, S. A. T. Bendiab, Composition and Antibacterial Activity of Pseudocytisus integrifolius (Salisb.) Essential Oil from Algeria, J. Agric. Food Chem., 53: 2947-2952, (2005).

5. N. S. Lacobellis, P. Lo Cantore, F. Capasso, F. Senatore, Antibacterial Activity of Cuminum cyminum L. and 
Carum carvi L. Essential Oils, J. Agric. Food Chem., 53: 57-61, (2005).

6. J-J. Fillipi, D-A. Lanfranchi, S. Prado, N. Daldovini, U. J. Meierhenrich, Composition, Enatiomeric Distribution, and Antibacterial Activity of Essential oil of Achillea ligustica All. From Corsica, J. Agric. Food Chem., 54: 6308-6313, (2006).

7. A. Olonisakin, M. O. Oladimeji, L. Lajide, Chemical Composition and Antibacterial Activity of Steam Distilled Oil of Ashanti Pepper (Piper guneense) Fruits Berries, Journal of Applied Siences, 6(11): 25202522, (2006).

8. S. L. Khokra, O. Prakash, S. Jaini, K. R. Aneja, Y. Dhingra, Essential Oil Composition and Antibacterial Studies of Vitex negundo Linn. Extracts, Indian J. Pharm. Sci., 70 (4): 522-526, (2008).

9. N. H. Jazani, G. Berenji, S. Sedegpoor, Antibacterial Effects of Iranian Menta pulegium Essential Oil on Isolates of Klebsiella sp, Pakistan Journal of Biological Science, 12(2): 183-185, (2009).

10. N. H. Jazani, M. Zartoshti, S. Sahabi, Antibacterial effects of Iranian Cuminum cyminum Essential Oil on Burn Isolates of Pseudomonas aeruginosa, International Journal of Pharmacology, 4(2): 157-159, (2008).

11. "http://en.wikipedia.org/wiki/Toona",02:15 pm, October 26, 2006.

12. D. F. Djam'an, Toona sureni (Blume) Merr, Seed Research Development and Technology Centre, Bogor, SEED LEAFLET, No. 82 August, 2003.

13. W. Kraus, K. Kypke, Surenone and Surenin, Two Novel Tetranortriterpenoids from Toona sureni (Blume) Merrill, Tetrahedron Letters, 20(29): 2715-2716, (1979).

14. W. Kraus, K. Kypke, M. Bokel, W. Grimminger, G. Sawitzki, G. Schwinger, Liebigs Annalen, 87-88, (1982).

15. H. Nurdin, S. Ibrahim, A. Darma, S. Rajagukguk, M. H. Muchtar, Sugiyanto, Isolation of carotenoid from Toona sureni (Blume) Merr Leaves, Proceeding International Symposium on The Role of Chemistry in Industry and Environment, Padang, (2000).

16. H. Nurdin, M. H. Muchtar, Sugiyanto, V. Dewi, Biologycal Activity of $\beta$-carotene Isolated from Toona sureni (Blume) Merr Leaves, International Seminar on Tropical Rainforest Plants and Their Utilization for Development, Padang, (2001).

17. H. L. N. S. Maia, Beatriz et al, Essential Oils of Toona and Cedrela Species (Meliaceae): Taxonomic and Ecological Implications, J. Braz. Chem. Soc.,11(6): 629-639, (2000).

18. A. Santoni, H. Nurdin, Y. Manjang, S. A. Achmad, Minyak Atsiri Dari Toona sinensis Dan Uji Aktivitas Insektisida, $J$. Ris.Kim., 2(2): 101-106, (2009).

19. AFNOR. Normes Francüaises, NF T 75-01, November 1999.

20. J. Rojas, J. Velasco, A. Morales, T. Díaz, G. Meccia, Evaluation of Antibacterial Activity on Different Solvent Extracts of Euphorbia caracasana Boiss and Euphorbia cotinifolia L. (Euphorbiaceae) Collected in Venezuela, Bol. Latinoam. Caribe Plant. Med. Aromaticas, 7(4): 198201, (2008). 